Andrew R. Lewis*

\title{
The Transformation of the Christian Right's Moral Politics
}

\author{
https://doi.org/10.1515/for-2019-0001
}

Abstract: For at least the past four decades, the Christian Right's political advocacy has epitomized morality politics in the US. In recent years, however, the Christian Right has transformed how it approaches various moral and cultural issues, appealing to the language and process of political rights. This reframing of cultural concerns has coincided with the declining cultural status of conservative Christianity. This article analyzes three issue areas-abortion, free speech, and religious freedom-documenting how conservative Christianity has altered its approach to public politics, coming to embrace individual rights language and arguments over and above common morality. The article also analyzes the whether this growing rights talk has contributed to extending support to the rights of others, finding mixed results. As conservative Christians have embraced the rights commitment for themselves, there has been a corresponding growth of political tolerance for others. At the same time, there remain prominent challenges to supporting pluralistic politics. While questions about the commitment to pluralism remain, the evolution of the Christian Right's cultural style of politics has important implications, as the last vestige of communitarian politics routinely engages politics using the language of liberalism. Moral politics are now routinely rights politics.

\section{Introduction}

Two of the headline US Supreme Court cases decided at the end June 2018 featured typical conflicts over "culture war" issues - abortion and gay rights. These cases however, do not simply represent a continuation of the cultural battles prominent for the past 45 years. Instead, they epitomize the transformation of the culture wars, especially on the Right. The two cases, Masterpiece Cakeshop v. Colorado Civil Rights Commission and National Institute of Family Life Advocates (NIFLA) v. Becerra, are excellent representations of the ongoing shift in the Christian Right's legal and political strategy. Conservative Christianity has forgone much of its "moral majoritarian" approach to cultural politics that was dominant

*Corresponding author: Andrew R. Lewis, University of Cincinnati, Cincinnati, OH, USA, e-mail: andrew.lewis@uc.edu 
throughout the 1980s and 1990s for a "cultural minority" strategy that wields the language of political liberalism, heavily emphasizing freedom and political rights. Not only has the Christian Right embraced the language of liberalism, but it has increasingly embraced certain values of liberalism. These include a more libertarian view of political rights, political pluralism, and secular political justifications. ${ }^{1}$ While this extension of liberal values to others (specifically advancing reciprocal rights) has been episodic, the growth of the Christian Right's rights culture and its embrace of a more liberal public politics is a profound change in the politics of morality. Increasingly, public culture war battles are waged in the language of liberalism.

The Christian Right's turn toward liberal public politics is evident in the Masterpiece and NIFLA cases. In terms of conservative Christian legal arguments, both cases are very similar. In Masterpiece, the question was whether a baker could be compelled by non-discrimination laws to bake a custom wedding cake for a same-sex couple. This case arose out of a conflict between a Denver-area bakery and a same-sex couple, Charlie Craig and David Mullins. The couple approached the baker, Jack Phillips, to create a cake celebrating their same-sex wedding. Phillips declined to make a cake for the event, citing his religious beliefs that forbid same-sex marriage. Craig and Mullins brought a complaint against Phillips to the Colorado Civil Rights Division, accusing him of violating the state's non-discrimination law. The agency ruled against Phillips, and this ruling was upheld by the Colorado Civil Rights Commission as well as a Colorado court.

At the US Supreme Court, Alliance Defending Freedom (ADF), the conservative Christian legal advocacy organization, delivered an appeal on behalf of Phillips and his bakery. In their written and oral arguments, ADF's strategy was not to argue that same-sex marriage was immoral or that the Colorado nondiscrimination policy was unconstitutional. Rather, it emphasized that in this particular case the nondiscrimination ruling was forcing their client (Phillips) to engage in "compelled speech," a core concern of liberal free speech doctrine. Essentially, the government was forcing artistic expression upon someone who had an unfavorable view. In its decision, the Supreme Court sidestepped the free speech issue, instead granting a qualified victory for Phillips by declaring that the Colorado Civil Rights Commission must take seriously his religious freedom claims. Despite the decision, free speech rights and religious freedom rights weighed heavily on the case and future cases that will surely follow.

NIFLA contains strikingly similar arguments, though with a slightly different outcome. The dispute in NIFLA is from California legislation seeking to regulate

1 For a discussion of political liberalism, generally see: Mill 2011 [1859]; Rawls (1971, 2005); Gutmann and Thompson (1996). 
anti-abortion "crisis pregnancy centers," typically supported by Catholics and evangelical Protestants. The Reproductive Freedom, Accountability, Comprehensive Care, and Transparency Act, also known as the Reproductive FACT Act, is aimed at these centers, which provide aid, counseling, and sometimes medical care to pregnant women. California was concerned that the pregnancy centers were providing misleading information to pregnant women, so it required that the pro-life organizations post a notice about the availability of low-cost abortions, if medical care is provided at the center, or include disclaimers about their services if no medical care is provided.

The pro-life pregnancy centers opposed these requirements, arguing that they had been unfairly targeted, since only anti-abortion centers must provide this information, and calling the requirements violations of their rights to free speech. In making their argument, the legal team for the crisis pregnancy centers, $\mathrm{ADF}$, again drew heavily upon the compelled speech doctrine, arguing that the government cannot force citizens to engage in speech without weighty justification. In a 5-4 decision, the Supreme Court agreed that the legislation infringed on the free speech rights of the centers.

The emphasis on the minority rights of free speech (and religious freedom) is not something novel in Masterpiece or NIFLA. Rather, it represents a growing trend in conservative (and particularly conservative Christian) legal advocacy in the US. Conservative Christians now champion their rights before courts and in politics. In the previous generations' culture wars, conservatives primarily emphasized common morality and maintaining order, while liberals emphasized rights and seeking equality. The Right featured the "Moral Majority" and the "Silent Majority," with the Left engaged in a "rights revolution." The Right warned about too much "rights talk" and sought to protect the ability of religious conservatives to make religiously-informed arguments about public morality. Despite these hesitations, the Right has now joined the Left in employing broad individual rights claims.

From a cultural change standpoint, these are monumental developments. Broad individual rights to free speech (including compelled speech) and religious freedom (including legal exemptions) have typically been championed by liberals and opposed by conservatives during their time. For example, advocating for expansive free speech rights, even religiously insensitive speech, is quite new for American evangelicals. For most of the 20th century, it was liberals and radicals who supported extensive free speech rights. Evangelicals considered these groups antithetical to American moral values, as they often supported pornography and sexualized art, while defying American patriotism. The primary compelled speech case, West Virginia State Board of Education v. Barnette (1943), which is cited prominently by the conservative Christians in both NIFLA and Masterpiece, 
involved Jehovah's Witness students who objected to being required to salute the flag. Conservatives, traditionally supporters of patriotism, have come to wield Barnette in their defense.

For conservative Christians, the rights to free speech and religious freedom are now at the forefront of both their political and legal engagement. In large part, this shift toward rights has been facilitated by losses in the culture wars. Conservative Christianity's cultural status has been on the decline, facilitating an embrace of rights and pluralism, at least rhetorically. In addition, as the Christian Right has become more professionalized and more ingrained in party politics, secular (and often liberal) justifications for their policies have increased. But is this shift toward rights merely a continuation of Christian Right morality politics, shrouded in the language of liberalism? While the results are mixed, the totality of the evidence suggests that the values of political liberalism, particularly the commitment to political rights, are being increasingly adopted by conservative Christianity.

Conservative Christian politics have been refashioned, adjusting how cultural conflict in waged America. Cultural politics increasingly features competing rights, but it has also delivered some growing political tolerance on the Right. The outcome is that the politics of Jerry Falwell's "Moral Majority" are substantially different than the politics of twenty-first century Christian Right.

\section{Moral Politics and the Rise of a Conservative Christian Rights Culture}

In many ways, individual rights are the common parlance of American politics (e.g. Hartz 1955; Jelen 2005), though certainly American society contains multiple political impulses (see e.g. Smith 1993). The discourse or rights, however, has long been the primary domain of liberals and progressives (e.g. Epp 1998; Rawls 2005), with conservatives often pushing back against the liberal "rights revolution" in favor of community norms, morality, and majoritarian processes (e.g. Glendon 1991; George 1995). Sociologist Robert Bellah and his colleagues (1985) described these cultural strains, suggesting that liberals emphasized utilitarian individualist and expressive individualist values, while conservatives stressed biblical and/or republican values.

This narrative is typical in the historiography of the rise of the Christian Right in the second half of the twentieth century. Conservative Christians were activated on various conservative cultural issues, including politics of sexuality, race, the family, and Christian nationalism, largely in response to the liberal and 
progressive forces (e.g. McGirr 2001; Williams 2010; Dochuk 2011; Kruse 2015). This helped spawn Jerry Falwell's Moral Majority, the increasing white evangelical mobilization in the 1980 presidential election, and the growing integration between the Christian Right and the Republican Party (Kohut et al. 2000; Layman 2001; Baylor 2018). Falwell's organization sought to activate a conservative, cultural majority to push back against liberal progressivism, emphasizing right and wrong, biblical morality, and traditional values (Williams 2010).

These competing typologies, orthodox conservatives versus progressive liberals, reverberated through American cultural politics, both in academic scholarship and journalism (see e.g. Wuthnow 1988; Hunter 1991). James Davison Hunter's Culture Wars and Pat Buchanan's 1992 Republican National Convention speech are two of the most prominent examples.

Over the past 20 years, however, the landscape of conservative discourse has evolved, particularly among the Christian Right. It has become more professionalized (Moen 1992; Layman and Brockway 2018; Wilson and Hollis-Brusky 2018), more attuned to legal arguments (Wilson 2013; Bennett 2017; Lewis 2017), and more rights-centric, especially regarding free speech (Brown 2002; Jelen 2005; Shields 2009; Djupe et al. 2014; Lewis 2017).

There are several arguments for the growth of the Christian Right's rights culture, including the building of professional legal organizations (Wilson 2013), the integration into the Republican Party (Moen 1992; Shields 2009), and the prolife movement's emphasis on individual rights (Lewis 2017). A common thread, however, is that as the Christian Right's cultural influence has declined (see e.g. Jones 2016). As such, framing their arguments in more neutral, publicly accessible language is advantageous, both in courts and in the court of public opinion (Jelen 2005; Shields 2009; Djupe et al. 2014; Lewis 2017). The result is that religious conservatives, the last stronghold of communitarianism in American politics have come to embrace rights talk - the language of liberalism - in much of their political discourse. The culture has changed, and so have their tactics. Going forward, the big question is whether this is merely rights talk for their own purposes, or if the embrace of rights will yield a stronger commitment to the liberalism project. To date, while there has been progress, the evidence is mixed.

\section{Evidence of the Growth of Rights Talk}

The Christian Right's approach to politics has seen a transformation in recent decades. The focus has been to emphasize more liberal values of rights and liberty, instead of communitarian values of cultural morality. To these ends, the Christian Right has increasingly pitched itself as a threatened minority, rather 
than a silent or moral majority. Minority politics promotes a more rights-centric public engagement. Three prominent advocacy areas highlight this shift: abortion, free speech, and religious freedom.

\section{Abortion}

The pro-life movement in America pre-dates the 1973 Roe v. Wade decision, and many of its early leaders came out of New Deal liberalism. As such, in the early parts of the movement strong rights-based arguments developed in opposition to abortion, particularly emphasizing the right-to-life. This liberal ethos was proffered primarily by Catholics and liberal Protestants, and this influence was evident in the formation of the National Right to Life in 1968 (Williams 2016). Evangelicals were slower to join the pro-life movement, and when they did join toward the end of the 1970s, evangelical leaders were more likely to emphasize abortion as being immoral, a part of the decline in cultural values rather than the rights of the unborn. Yet, a strain of rights-based opposition to abortion persisted, and over time this rhetorical approach prevailed (see, Lewis 2017).

Evangelicals' entre into the anti-abortion movement was facilitated by a few prominent religious leaders who vociferously opposed abortion (Williams 2010; Lewis 2017; Baylor 2018). Two of the most integral were Francis Schaeffer, the theologian and cultural critic, and Jerry Falwell, the televangelist and political organizer. This early evangelical anti-abortion advocacy was characterized by a strong emphasis on morality, right and wrong. Falwell best represents this approach. His opposition to abortion was pitched as a broad moral concern related to the downfall of Christian morality, typically fused with his disdain of sexual freedom, the Equal Rights Amendment (ERA), gay rights, and secular humanism. In How You Can Help Clean Up America, Falwell linked abortion with feminism and promiscuity, suggesting that women seek abortions after becoming "pregnant because of sin" or because they had been "caught up in the ERA movement and want to terminate their pregnancy because it limits their freedom and their job opportunities” (Falwell 1978, pp. 60-61; see also: Williams 2010; Lewis 2017).

Schaeffer too couched his opposition to abortion in moral decline, evident in his books and films such as How Should We Then Live? and Whatever Happened to the Human Race. His persistent theme was that a cultural and political shift away from biblical sexual ethics was responsible for abortion being legal (Hankins 2008; Williams 2010). At the same time, Schaeffer also emphasized the human rights and human dignity of the unborn, drawing upon the more liberal, human rights themes found mostly in Catholic activists (Hankins 2008; Williams 2010; Lewis 2017). 
By the end of the 1980s, however, the pro-life movement had largely coalesced around the more liberal rhetoric. Analyses of survey data indicated that evangelicals were not motivated by rights-based justifications against abortion in the early 1980s, but by the end of the decade they were (Jelen 1984, 1988). This fits with other analyses of the Christian Right which suggests it intentionally emphasized more liberal, rights-based public rhetoric by the end of the 1980s (Moen 1992). In 1994, Matthew Moen described, "Virtually all of [the Christian Right's] issues have been recast” (Moen 1994, p. 352; see also: Reed 1996).

Resolutions from the Southern Baptist Convention (SBC), the largest evangelical denomination in the US, highlight this shift toward framing their positions in the language of liberal human rights (see, Lewis 2017), though the SBC is not alone. In 1980, the SBC altered its approach to abortion, delineating a decidedly pro-life position. In their resolution, they decried "selfish, non-therapeutic abortion," calling for an anti-abortion amendment (Resolution on Abortion 1980). By 1996, in a resolution condemning partial-birth abortion, the SBC emphasized the "sanctity of the innocent, unborn babies" and working for "civil justice for these innocent victims" (Resolution on the Partial-Birth Abortion Ban 1996). In 2015, the denomination's resolution called on its members to work "on behalf of justice, the protection of human life, and the cause of human flourishing" (On the Sanctity of Human Life 2015). The evolution is clear. Moralizing had given way to human rights.

\section{Free Speech}

For most of the twentieth century, evangelicals and other conservative Christians took a restrictive approach to free speech. Opposition to obscenity and pornography was one of the most frequent advocacy positions of groups like the SBC and the National Association of Evangelicals. They also opposed radical protests, flag burning, and exceptions to saying the pledge of allegiance (see, Lewis 2017). Protecting community morality was to be preferred to promoting individual liberties.

Over the past few decades, however, there has been a shift in conservative Christian political and legal advocacy. Broad emphasis on expanding free speech has become primary emphasis of Christian Right's legal and political advocacy.

The changing perspectives on free speech began in service of conservative Christian interests. Christian Right advocates championed free speech in defense of Christian broadcasters and in opposition to the Federal Communication Commission's Fairness Doctrine (see, Hendershot 2011). In the legal realm, conservative Christian free speech arguments were marshaled to help promote the 
participation of religious groups and individuals in the public square. Advocates refashioned their approach to the religion clauses to argue that free speech principles should override concerns about promoting the strict separation of church and state. These claims were quite successful, including several victories before the US Supreme Court (Brown 2002). For example, liberal free speech principles were leveraged to support religious student groups getting access to public university funds and public school facilities.

The importance of free speech arguments grew in the 1990s, as pro-life organizations were entangled in legal battles over their right to protest and engage in various forms of activism outside abortion clinics. The array of legal battles saw the pro-life groups develop strong free speech defenses on their activism, building on the right to protest that had been established in favor of liberal causes several decades prior. These cases also precipitated the establishment of many Christian legal organizations that became leaders in promoting free speech ideology on the Right (Wilson 2013). In the most recent case in this line, McCullen $v$. Coakley (2014), a coalition of conservative Christian groups argued that protest restrictions around reproductive health care facilities were an unconstitutional restriction on free speech. In doing so, they deployed the most liberal legal precedents in their defense, including Cohen v. California (1971). These prior free speech rulings, championed in McCullen, would have been despised by conservative Christians a generation ago.

Pro-life leaders and organizations also developed free speech defenses against campaign finance reform, joining other conservative legal groups. After the passage of the Bipartisan Campaign Reform Act, also known as McCainFeingold, one of the earliest cases that challenged the constitutionality of the bill was brought by Wisconsin Right to Life, the state chapter of the national antiabortion organization (Federal Election Commission v. Wisconsin Right to Life 2007). The most notable constitutional restriction on the Act happened in Citizen's United v. Federal Election Commission, where the Supreme Court ruled 5-4 that part of the bill's provisions were an unconstitutional restriction on political speech. James Bopp was one of the lawyers who argued the case, and he had strong ties to the Christian Right, especially National Right to Life. He had also previously litigated the Wisconsin Right to Life case (for more, see: Lewis 2017). Other cases saw Christian Right groups argue that campaign reforms limited their free speech, including Susan B. Anthony List v. Driehaus (2014), an Ohio case where a pro-life group's free speech rights prevailed over restrictions on false statements in campaign advertisements.

This evolution on free speech is joined by the two cases from 2018 highlighted in the introduction. Conservative Christian advocates developed extensive arguments against what they deemed to be compelled speech in Masterpiece Cakeshop 
v. Colorado Civil Rights Commission and NIFLA v. Becerra. The compelled speech argument prevailed in NIFLA, but in Masterpiece the Court eschewed it in favor of a narrow decision that the baker's religious freedom rights had been violated.

While the Christian Right's engagement with free speech legal and political advocacy has been primarily been used to support the free speech of Christian individuals and organizations, many religious groups have also come to the defense of others' free speech under the auspices of expanding the sphere of free speech for disfavored groups. Several conservative Christian groups supported a student who was suspended for holding a "Bong Hits 4 Jesus" sign during an event where the school was released to watch the Olympic torch relay (Morse v. Frederick 2007). Conservative Christian organizations also defended the free speech rights of the radical Westboro Baptist Church, which was being sued for damages after picketing the funeral of an American soldier (Snyder v. Phelps 2011). In fact, prominent leaders came around to the importance of the free speech, after initially strongly opposing the church (see, Cummings 2010). The Becket Fund for Religious liberty also filed an amicus brief supporting the broad free speech and free association rights of a public employee who was punished for his perceived political views (Heffernan v. City of Patterson 2016).

As broad free speech rights have become an emphasis among conservative Christian advocacy groups, evangelical Christians have increasingly altered their opinions on extending free speech rights to disfavored groups. Figure 1 presents data from the General Social Survey (GSS), which since the 1970s has asked whether respondents would extend free speech rights to racists, atheists, homosexuals, communists, and militarists. Evangelicals have long trailed the general public in their support for free speech, but over the past three decades, the rate of support has increased substantially, nearly catching the general public. In fact, evangelicals under 50 (dotted line) almost mirror non-evangelicals over the past decade, closing the gap from earlier decades. ${ }^{2}$

The increase in evangelical's tolerance for the political speech of disfavored groups suggests a growing importance on the Right about the absolute value of free speech, not only for themselves. As Christian Right organizations have been championing rights-based politics, and the dynamics of cultural politics have changed, the rank-and-file have updated their views. Such findings also mirror broader analyses on trends in political tolerance that suggest that evangelicals' tolerance increased at the greatest rates (Eisenstein, Clark, and Jelen 2017).

While the Christian Right advocacy has progressively emphasized free speech built upon broad individual rights, it has continued to promote limited

2 With the GSS data, evangelicals are measured by affiliation with an evangelical denomination, following the approach of Steensland et al. (2000), updated by Stetzer and Burge (2016). 


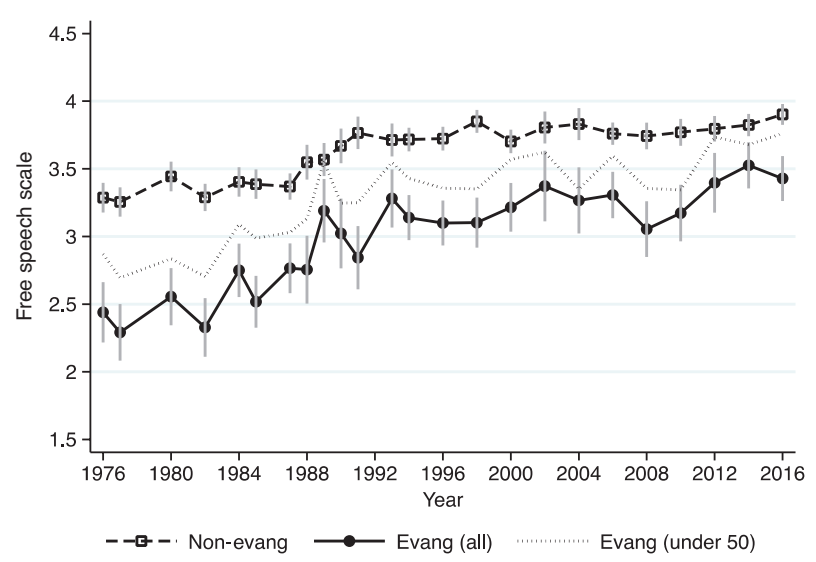

Figure 1: Evangelical and Non-Evangelical Support for Free Speech over Time, Using 5-Item Free Speech Scale (0-5). General Social Survey, 1975-2016.

rights in the area of pornography and obscenity. In 1993, several evangelical groups (and other religious organizations) filed briefs supporting tough obscenity standards (Alexander v. United States of America 1993), and many organizations have also opposed free speech arguments to promote various forms of pornography (e.g. United States of America v. X-Citement Video 1994; Ashcroft v. American Civil Liberties Union 2002). Since there is no connection between conservative Christians' anti-abortion advocacy and supporting free speech for pornographers, this has remained the exception. Conservative Christian groups continue to oppose pornography and obscenity, and evangelical public opinion shows consistent opposition, while the general public has liberalized.

At the same time, however, evangelicals' attention to advocating against pornography and obscenity has declined markedly since the middle of the twentieth century. This might suggest evidence of the tension in their free speech agenda, or it might also be a function of the legality of pornography being settled and/or other issues crowding out the ability of groups to pay attention to pornography. On the whole, however, conservative Christians have become more supportive of broad free speech rights, particularly political speech. Inflecting their advocacy has been useful to their agenda, especially as their cultural status has declined.

\section{Religious Liberty and LGBT Rights}

More so than free speech, religious liberty has long been a component of Christians' political and legal advocacy. Yet, the emphasis on religious liberty has 
evolved importantly in the wake of the legalization of same-sex marriage and the growth of LGBT rights in the US. Over the past 15 years, religious liberty politics have become increasingly prevalent on the Right, helping to polarize the issue.

Religious freedom and freedom of conscience have been an important component of the American rights culture (McLoughlin 1991; for the Western development, which was adapted to the US, see: Witte 2007). Religious freedom, however, was often paired with a version church-state separation that sought to protect white Protestant majoritarianism (Hamburger 2002). For much of the twentieth century, religious freedom was championed by religious minorities such as Jehovah's Witnesses, Mormons, and Jews, as a way to secure the individual rights to practice their religion in a largely Christian (and Protestant) country. The Supreme Court's Everson v. Board of Education (1947) decision applied the US. Constitution's provision against establishing religion to the states and erected a "high wall of separation between church and state" in American law. Its progeny, including cases outlawing prayer and bible readings (Engle v. Vitale and Abington Township v. Schempp) and a case establishing a stringent test against churchstate establishments (Lemon v. Kurtzman 1971), solidified the wall of separation. These cases also helped conservative Christians cultivate an approach that used religious freedom rights as a tool to combat the Establishment Clause limitations. The most prominent example of this was the School Prayer Amendment, which was a part of the Congressional agenda at various times between the 1960s and 1990s and supported by President Reagan in 1982. Court cases followed, with the Christian Right and their allies seeking to allay Establishment Clause concerns by emphasizing religious freedom (see e.g. Lynch v. Donnelly 1984; Wallace v. Jaffree 1985; Lee v. Weisman 1992). Religious freedom was effectively used as a tool to promote the Christian, moralistic majority against the Establishment Clause limitations, altering the Right's priorities (Lewis 2014).

While religious freedom was being proffered to support a version of a Christian establishment, other streams were supporting more pluralistic approaches to religious freedom. This included the legal push for using free speech and free assembly claims for religious groups and individuals to gain access to public facilities and funding (Brown 2002), as well as the bipartisan federal Equal Access Act (1984). The success of these free speech and equal access provisions catapulted them to the prominent position within Christian Right advocacy. Over the next few decades, conservative Christian religious freedom advocacy (and free speech) increasingly took on a more pluralistic character, at least publicly. This is evident in the way that organizations (and the Supreme Court) approached a variety of church-state issues. If public religious displays were pluralistic, rather than exclusive, then they seemed to pass constitutional muster (e.g. Lynch v. Donnelly 1984; County of Allegheny v. ACLU 1989; Van Orden v. Perry 2005). If religious 
groups were one of many types of groups seeking access to public facilities, such as meeting space in public schools (Lamb's Chapel v. Center Moriches Union Free School District 1993), money doled out to student organizations at public universities (Rosenberger v. University of Virginia 1995), or government vouchers to attend private school (Zelman v. Simmons-Harris 2002), then the Establishment Clause could not bar religious access. In fact, a government prohibition would be a denial of First Amendment liberties, namely religious freedom and free speech.

Over the past few decades, conservative Christian advocates altered their First Amendment advocacy, emphasizing individual rights. Growing cultural pluralism and the Supreme Court's standards prompted this shift.

\section{Shift to Religious Freedom in the Gay Rights Debate}

While conservative Christian advocates have embraced individual religious freedom rights to secure their rights to participate in the public square, often with pluralistic language, they have also turned toward religious freedom in the debates over gay rights. In doing so, they have left behind a good portion of their moralistic politics of the past.

For the past five decades, conservative Christians have opposed the expansion of gay and lesbian rights and sexual liberalization. In doing so, they often framed same-sex relations and same-sex marriages as immoral and unnatural. The general perspective in their approach to the issue was to preserve the moral standards of the community - opposing the rights gay and lesbian individuals, not protecting their own. A host of data explicates this perspective (see, Lewis 2017).

In 1976, the Southern Baptist Convention went on record urging churches to oppose gays and lesbians any "designations of normal life-style" (Resolution on Homosexuality 1976). In 1980, the Convention condemned gay activists for their seeking to pass ordinances under the "deceptive guise of human rights" and characterized same-sex relations as "sexual perversion" (Resolution on Homosexuality 1980) - similar to how evangelical doctor and activist James Dobson describes homosexuality in his popular parenting book (Dobson 2001). Similar rhetoric continued in resolutions in 1988 and 1993. On the national level, the SBC, the National Association of Evangelicals, and leaders of the Catholic church strongly opposed gays and lesbians serving in the military, seeking to protect moral standards ("Religious Leaders Divided over Gays in Military" 1993; Resolution on Homosexuality, Military Service and Civil Rights 1993). In Colorado, the group Colorado for Family Values organized evangelical churchgoers to pass Amendment 2 to the Colorado constitution, forbidding the state from granting protected status based on sexual orientation (Johnson 1992). When Amendment 
2 was challenged before the US Supreme Court as a denial of rights, the Supreme Court struck down the amendment, arguing that it was based on animus, not rationality (Romer v. Evans 1995). In a stinging dissent, Justice Scalia summarized that moral disapproval had been described as animus and irrationality, suggesting that for laws regarding sexual morality the end for was near.

The story is similar for same-sex marriage. When Hawaii's Supreme Court required a compelling state interest to deny same-sex marriages in the mid-1990s, which the state ultimately could not prove, the Family Research Council declared that the ruling denied "not only the wisdom of generations but the law of nature and nature's God” (Goldberg 1996). As the legal debate over same-sex marriage was taking place in Hawaii, the SBC developed its case opposing same-sex marriage, asserting that there is much scientific evidence showing that "homosexual attractions are pathological, abnormal, and mostly if not entirely a matter of external influence, learned behavior, acquired taste and personal choice.” Further, its resolution declared that "recognition of homosexual marriages ... will certainly undermine, and may even restrain, the public communication, influence, and independence of individuals, groups, and institutions" who view gay marriage as immoral (Resolution on Homosexual Marriage 1996). Such a morality-centered perspective was typical of evangelical advocacy on the issue through most of the 2000s.

Despite these strong moralistic perspectives, as public opinion was becoming more supportive of gay rights and same-sex marriage and the legal system was declaring bans on same-sex marriage unconstitutional, the conservative Christians adjusted their approach to gay rights. The evolution was not to acceptance, but to seeking to defend their own rights in a culture that supports samesex rights and enforces non-discrimination of LGBT individuals. Religious liberty was marshaled to promote a pluralistic society that extended protections for conservative Christianity.

This evolution preceded the Supreme Court Obergefell v. Hodges decision in 2015 that declared same-sex marriage legal throughout the US. There was some early evidence of this shift in the legal advocacy, particularly a conservative Christian amicus brief in Romer v. Evans (Strode 1995), the Supreme Court case which declared Colorado's Amendment 2 unconstitutional. But the emphasis on religious freedom exploded just prior to the Obergefell decision, as the writing was on the wall. The years prior, activists promoted state-level religious freedom bills to enhance religious freedom protections, seeking to help protect individuals and organizations from facing non-discrimination penalties. The most controversial was Indiana's Religious Freedom Restoration Act (see, Cook 2015). In the moments following the Supreme Court's decision in Obergefell, the senior counsel for Alliance Defending Freedom spoke at a press conference on the steps of the Supreme Court, declaring, "We hope that this decision today will not be 
used as an excuse to ostracize, to demonize, or to punish people for holding views contrary to what five of the nine justices said today" (NBC Nightly News 2015; see also: Williams and Abdullah 2015).

In the 4 years since Obergefell, the Christian Right has extended very little energy in overturning the decision and establishing that state laws that restrict gay marriage are constitutionally acceptable. Rather, its efforts have been concentrated on trying to expand individual religious freedom rights so that individuals and organizations who oppose same-sex marriage do not have to abide by generally applicable non-discrimination laws. The Masterpiece Cakeshop case, the state religious freedom laws, and the Trump Administration's religious freedom initiatives typify that approach. Preserving societal morality has given way to protecting individual conscience, a signal of the waning cultural and political support for conservative Christian views on gay rights. The right to religious freedom now stands at the forefront of their efforts in this area.

\section{Tensions in Religious Freedom Activism}

While religious liberty has become elevated in conservative Christian advocacy, there remain important tensions in the movement's approach to the issue. Several organizations have been supportive broad religious freedom rights for all types of religious minorities, including a Hasidic Jews (Kiryas Joel Village $v$. Grumet 1994), Santeríans (Church of Lukumi Babalu Aye v. City of Hialeah 1993), a Muslim prisoner (Holt v. Hobbs 2015), and a Muslim mosque (Green 2017a; Lewis 2017, 2018). Yet, conservative Christian groups are generally most active in supporting the religious freedom claims of conservative Christians, with some organizations and activists noting their hostility to the religious freedom of Muslims (see e.g. Bennett 2017). Notably, there was scant activity from conservative Christian groups pushing back against the Trump Administration's travel ban, which targeted several majority-Muslim countries, due to religious freedom concerns (Boorstein 2018). Some prominent groups, such as the American Center for Law and Justice, even publicly supported it, declaring the Supreme Court upholding of the travel ban a "tremendous victory in ongoing efforts to defend and protect America” (American Center for Law and Justice 2018).

These tensions regarding religious freedom are reflected in the survey data of evangelicals. Over the past two decades, attention to religious freedom has grown on the Right, as evangelicals see religious freedom as threatened. Figure 2 shows data from evangelical clergy, demonstrating an exponential rise in these sentiments. There is growing fear that religious liberty is under attack, especially for conservative Christians. (For more public opinion and religious freedom, see also: Castle 2017, 2018). 


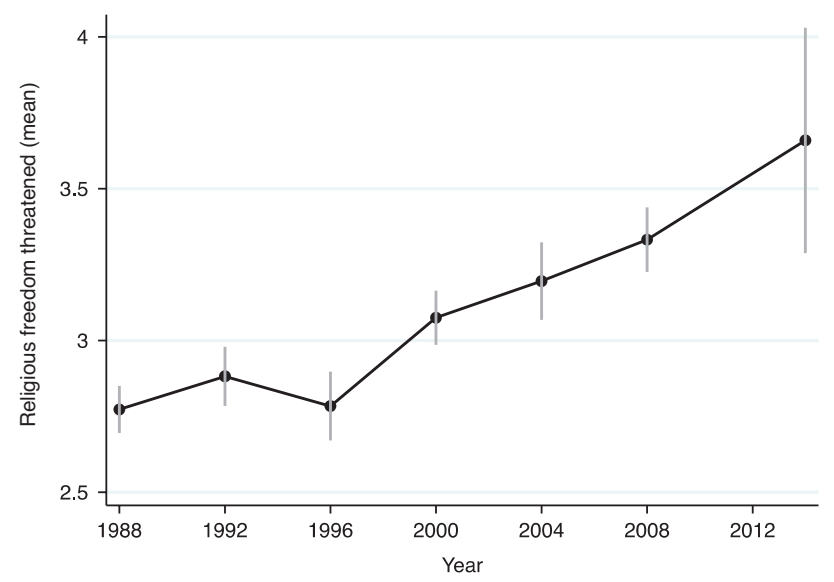

Figure 2: Average Rating of Evangelical Clergy Agreeing that Religious Freedom is Threatened in the US, 1988-2014 (1-5 Scale). Combination of Southern Baptist Clergy (1988-2008) and Evangelical Clergy (2014).

Importantly, the growing salience of religious freedom for the in-group, conservative Christians, seems to have spillover effects regarding support for religious freedom for everyone, much like free speech. National survey data asking about support for religious freedom is limited, but the General Social Survey has asked about support for the political rights of atheists, which serves as a decent proxy. Figure 3 shows the trends from 1972 to 2016. As in Figure 1 above,

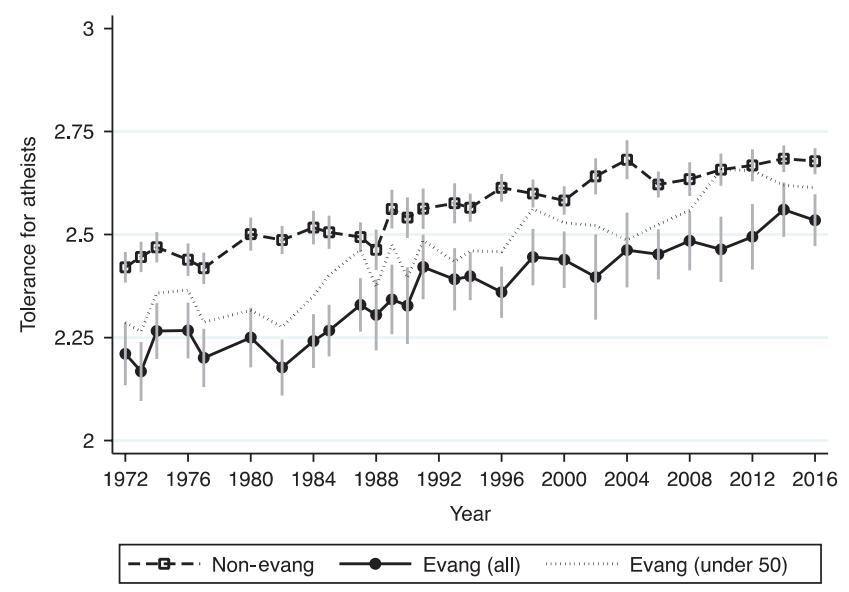

Figure 3: Evangelical and Non-Evangelical Support for Religious Liberty of Atheists over Time, Using 3-Item Tolerance Scale (0-3). General Social Survey, 1972-2016. 
evangelicals consistently trail the non-evangelical population, but evangelicals' tolerance for atheists has increased at a greater rate over the span, closing much of the gap. Like free speech, evangelicals under 50 (dotted line) now nearly match non-evangelical's support for atheists. In addition, experimental evidence suggests that when evangelicals are primed by statements of clergy members to consider their own religious freedom rights, they respond with greater tolerance toward least-liked groups (Djupe, Lewis, and Jelen 2016).

Though public opinion research shows some positive spill-over effects, there remain challenges. Muslims, along with atheists, are consistently at the top of the least-tolerated groups in American politics (Kalkan, Layman, and Green 2018), and conservative Christians have a particular bias against Muslims (Karpowitz, Monson, and Patterson 2016). White evangelicals, in particular, even view their own travails as worse than Muslims, rating that they face higher levels of discrimination (Green 2017b). Such an exclusive view of religious freedom has only polarized their rights claims more. Thus, while enhanced in-group rights consciousness, both in the legal and public opinion realms, seems to have promoted growing support for the political rights of others. Nevertheless, important limitations remain.

\section{Conclusion}

Political movements are dynamic, and the Christian Right is no exception. The past half century has seen a transformation in how conservative Christians approach politics, especially morality politics. A strong emphasis on public morality, majoritarianism, and communitarianism has been replaced with a heavy dose of human rights, minority rights, and liberalism. As some high-profile culture war battles have been lost and conservative Christian cultural influence has declined, many conservative Christian moral issues have been re-framed in the language of rights, appealing to America's liberal political culture. While the vast majority of this rights-based advocacy is in support of conservative Christian interests, evidence suggests that the approach is not just a veneer. Conservative Christians have become more committed to the political rights of others.

There are certainly major qualifications, as the Christian Right's commitment to rights is episodic and more theoretical than concrete (as is often the case). Moreover, the campaign and presidency of Donald Trump has re-opened a debate on the Right about how to approach conservative Christian political interests going forward (see Lewis 2018). Should they be focused on Christian nationalism or religious pluralism? In the near-term, the language of rights is being mostly used to promote Christian nationalist interests and many classic culture war 
interests (den Dulk 2018). At the same time, over the past five decades there has been a trajectory toward pluralism. The answer will come in time.

Despite these qualifications, using the categories of Robert Bellah and his co-authors (Bellah et al. 1985), conservative Christians have transitioned much of their public politics from biblical morality to a version of utilitarian individualism. This does not mean that conservative Christians are becoming progressives or will support all the expressive individual rights that liberals want, but it does suggest that contemporary politics, both in courts and the courts of public opinion, will continue to be waged using language of liberalism. The politics of morality have been refashioned.

In regard to American democracy, while the refashioning of moral politics may present opportunities for learning about liberal values, it also poses challenges. For example, this shift means that the most pressing cultural conflicts in America will feature competing rights. The right to be free from discrimination will be pitted against the right of religious freedom. Broad free speech rights will be countered with the rights of identity or bodily autonomy. In such clashes, it may be difficult to find acceptable solutions, as losers will sense that their fundamental rights are impinged (see e.g. Glendon 1991). Moreover, our most important conflicts will increasingly be settled by judicial bodies rather than legislative ones. The outcomes are likely to continue to promote the polarization of fundamental rights, as is evident with descriptions of rights being weaponized (e.g. Liptak 2018). These warnings, however, should be tempered by the fact that the American public has shown some capability of navigating compromises on competing rights (Jelen 2005; Djupe et al. 2014). No matter, for the foreseeable future, moral politics will often be rights politics.

\section{References}

American Center for Law and Justice. 2018. ACLJ: Supreme Court Upholding Travel Ban Represents a 'Tremendous Victory in Ongoing Efforts to Defend and Protect America'. American Center for Law and Justice.

Baylor, Christopher. 2018. First to the Party: The Group Origins of Party Transformation. Philadelphia: University of Pennsylvania Press.

Bellah, Robert N., Steve M. Tipton, William M. Sullivan, Richard Madsen, and Ann Swidler. 1985. Habits of the Heart: Individualism and Commitment in American Life. Berkeley, CA: University of California Press.

Bennett, Daniel. 2017. Defending Faith: The Politics of the Conservative Christian Legal Movement. Lawrence: University of Press of Kansas.

Boorstein, Michelle. 2018. "Why Many Religious Liberty Groups Are Silent About the Supreme Court's Decision on Trump's Travel Ban.” Washington Post, June 27, 2018. https://www. 
washingtonpost.com/news/acts-of-faith/wp/2018/06/26/why-many-religious-libertygroups-are-silent-on-the-supreme-courts-decision-to-uphold-trumps-travel-ban/?utm_ term $=.457731 \mathrm{cdba} 8 \mathrm{~d}$.

Brown, Steven P. 2002. Trumping Religion: The New Christian Right, the Free Speech Clause, and the Courts. Tuscaloosa: University of Alabama Press.

Castle, Jeremiah J. 2017. "Authoritarianism and Public Opinion on Church and State in the United States." Politics \& Religion 10 (1): 57-81.

Castle, Jeremiah. 2018. "New Fronts in the Culture Wars? Religion, Partisanship, and Polarization on Religious Liberty and Transgender Rights in the United States." American Politics Research 47 (3): 650-679.

Cook, Tony. 2015. “Gov. Mike Pence Signs ‘Religious Freedom’ Bill in Private.” Indiana Star, April 2, 2015. http://www.indystar.com/story/news/politics/2015/03/25/gov-mike-pencesign-religious-freedom-bill-thursday/70448858/.

Cummings, Hannah. 2010. "High Court Weighs Speech Limits in Westboro Case." Baptist Press, October 7, 2010. http://www.bpnews.net/33816.

den Dulk, Kevin. 2018. "The GOP, Evangelical Elites, and the Challenge of Pluralism.” In The Evangelical Crackup? The Future of the Evangelical-Republican Coalition, edited by Paul A. Djupe and Ryan L. Claassen, 63-76. Philadelphia: Temple University Press.

Djupe, Paul A., Andrew R. Lewis, Ted G. Jelen, and Charles D. Dahan. 2014. "Rights Talk: The Opinion Dynamics of Rights Framing.” Social Science Quarterly 95 (3): 652-668.

Djupe, Paul A., Andrew R. Lewis, and Ted G. Jelen. 2016. "Rights, Reflection, and Reciprocity: Implications of the Same-Sex Marriage Debate for Tolerance and the Political Process." Politics \& Religion 9 (3): 630-648.

Dobson, James. 2001. Bringing up Boys. Wheaton, IL: Tyndale House.

Dochuk, Darren. 2011. From Bible Belt to Sun Belt: Plain-Folk Religion, Grassroots Politics, and the Rise of Evangelical Conservatism. New York: W.W. Norton.

Eisenstein, Marie A., April K. Clark, and Ted G. Jelen. 2017. "Political Tolerance and Religion: An Age-Period-Cohort Analysis, 1984-2014." Review of Religious Research 59 (3): 395-418.

Epp, Charles R. 1998. The Rights Revolution: Lawyers, Activists, and Supreme Courts in Comparative Perspective. Chicago: University of Chicago Press.

Falwell, Jerry. 1978. How You Can Help Clean up America. Lynchburg, VA: Liberty Publishing Company.

George, Robert P. 1995. Making Men Moral: Civil Liberties and Public Morals. New York: Oxford University Press.

Glendon, Mary Ann. 1991. Rights Talk: The Impoverishment of Political Discourse. New York, NY: Free Press.

Goldberg, Carey. 1996. “Hawaii Judge Ends Gay-Marriage Ban.” The New York Times, December 4, 1996. https://www.nytimes.com/1996/12/04/us/hawaii-judge-ends-gay-marriage-ban.html.

Green, Emma. 2017a. "A New Jersey Mosque Wins in a Religious-Discrimination Lawsuit - over Parking Lots." The Atlantic, May 30, 2017. https://www.theatlantic.com/politics/ archive/2017/05/bernards-township-mosque-case-settled/528492/.

Green, Emma. 2017b. "White Evangelicals Believe They Face More Discrimination Than Muslims." The Atlantic, March 10, 2017. Accessed August 25, 2017. https://www.theatlantic. com/politics/archive/2017/03/perceptions-discrimination-muslims-christians/519135/.

Gutmann, Amy, and Dennis Thompson. 1996. Democracy and Disagreement. Cambridge: Belknap Press.

Hamburger, Philip. 2002. Separation of Church and State. Cambridge, MA: Harvard University Press. 
Hankins, Barry. 2008. Francis Schaeffer and the Shaping of Evangelical America. Grand Rapids, MI: Wm. B. Eerdmans.

Hartz, Louis. 1955. The Liberal Tradition in America: An Interpretation of Political Thought. New York: Harcourt, Brace, and World.

Hendershot, Heather. 2011. What's Fair on the Air: Cold War Right-Wing Broadcasting and the Public Interest. Chicago: University of Chicago Press.

Hunter, James Davison. 1991. Culture Wars: The Struggle to Define America. New York: Basic Books.

Jelen, Ted G. 1984. "Respect for Life, Sexual Morality, and Opposition to Abortion.” Review of Religious Research 25 (3): 220-231.

Jelen, Ted G. 1988. “Changes in the Attitudinal Correlates of Opposition to Abortion.” Journal for the Scientific Study of Religion 27 (2): 211-228.

Jelen, Ted G. 2005. "Political Esperanto: Rhetorical Resources and Limitations of the Christian Right in the United States." Sociology of Religion 66 (3): 303-321.

Johnson, Dirk. 1992. “Colorado Homosexuals Feel Betrayed.” The New York Times, November 8, 1992: L38.

Jones, Robert P. 2016. The End of White Christian America. New York: Simon \& Schuster.

Kalkan, Kerem Ozan, Geoffrey C. Layman, and John C. Green. 2018. "Will Americans Vote for Muslims? Cultural Outgroup Antipathy, Candidate Religion, and U.S. Voting Behavior.” Politics \& Religion 11 (4): 798-829.

Karpowitz, Christopher F., J. Quin Monson, and Kelly D. Patterson. 2016. “Who’s in and Who's out: The Politics of Religious Norms." Politics \& Religion 9 (3): 508-536.

Kohut, Andrew, John C. Green, Scott Keeter, and Robert C. Toth. 2000. The Diminishing Divide: Religion's Changing Role in American Politics. Washington, DC: Brookings Institution Press. Kruse, Kevin M. 2015. One Nation under God: How Corporate America Invented Christian America. New York: Basic Books.

Layman, Geoffrey. 2001. The Great Divide: Religious and Cultural Conflict in American Party Politics. New York: Columbia University Press.

Layman, Geoffrey, and Mark Brockway. 2018. "Evangelical Activists in the Gop: Still the Life of the Party?" In The Evangelical Crackup? The Future of the Evangelical-Republican Coalition, edited by Paul A. Djupe and Ryan L. Claassen, 32-48. Philadelphia: Temple University Press.

Lewis, Andrew R. 2014. "Abortion Politics and the Decline of the Separation of Church and State: The Southern Baptist Case." Politics \& Religion 7 (3): 521-549.

Lewis, Andrew R. 2017. The Rights Turn in Conservative Christian Politics: How Abortion Transformed the Culture Wars. New York: Cambridge University Press.

Lewis, Andrew R. 2018. "Divided over Rights: Competing Evangelical Visions for the TwentyFirst-Century America." In The Evangelical Crackup? The Future of the Evangelical-Republican Coalition, edited by Paul A. Djupe and Ryan L. Claassen, 77-93. Philadelphia: Temple University Press.

Liptak, Adam. 2018. "How Conservatives Weaponized the First Amendment.” The New York Times. June 30, 2018. https://www.nytimes.com/2018/06/30/us/politics/first-amendment-conservatives-supreme-court.html.

McGirr, Lisa. 2001. Suburban Warriors: The Origins of the New Right. Princeton, NJ: Princeton University Press.

McLoughlin, William. 1991. Soul Liberty: The Baptists' Struggle in New England, 1630-1833. Hanover, NH: University Press of New England. 
Mill, John Stuart. 2011 [1859]. On Liberty. New York: Cambridge University Press.

Moen, Matthew C. 1992. The Transformation of the Christian Right. Tuscaloosa: University of Alabama.

Moen, Matthew C. 1994. "From Revolution to Evolution: The Changing Nature of the Christian Right." Sociology of Religion 55 (3): 345-357.

NBC Nightly News. 2015. June 26, 2015. https://www.nbcnews.com/nightly-news/video/ supreme-court-strikes-down-same-sex-marriage-ban-472091715888.

On the Sanctity of Human Life. 2015. Columbus, OH: Southern Baptist Convention.

Rawls, John. 1971. A Theory of Justice. Cambridge, MA: Harvard University Press.

Rawls, John. 2005. Political Liberalism. expanded ed. New York: Columbia University Press.

Reed, Ralph. 1996. Active Faith: How Christians Are Changing the Soul of American Politics. New York: Free Press.

“Religious Leaders Divided over Gays in Military.” 1993. Los Angeles Times, April 3, 1993. http://articles.latimes.com/1993-04-03/local/me-18590_1_religious-leaders.

Resolution on Abortion. 1980. St Louis: Southern Baptist Convention.

Resolution on Homosexual Marriage. 1996. New Orleans, LA: Southern Baptist Convention.

Resolution on Homosexuality. 1976. Norfolk, VA: Southern Baptist Convention.

Resolution on Homosexuality. 1980. St. Louis, MO: Southern Baptist Convention.

Resolution on Homosexuality, Military Service and Civil Rights. 1993. Houston, TX: Southern Baptist Convention.

Resolution on the Partial-Birth Abortion Ban. 1996. New Orleans, LA: Southern Baptist Convention.

Shields, Jon A. 2009. The Democratic Virtues of the Christian Right. Princeton, NJ: Princeton University Press.

Smith, Rogers M. 1993. "Beyond Tocqueville, Myrdal, and Hartz: The Multiple Traditions in America.” American Political Science Review 87 (3): 549-566.

Steensland, Brian, Jerry Z. Park, Mark D. Regnerus, Lynn D. Robinson, W. Bradford Wilcox, and Robert D. Woodberry. 2000. "The Measure of American Religion: Toward Improving the State of the Art.” Social Forces 79 (1): 291-318.

Stetzer, Ed, and Ryan P. Burge. 2016. "Reltrad Coding Problems and a New Repository." Politics \& Religion 9 (1): 187-190.

Strode, Tom. 1995. “CLC Joins Brief Opposing Ruling for Homosexual Rights.” Baptist Press, July 28, 1995: 4-5.

Williams, Daniel K. 2010. God's Own Party: The Making of the Christian Right. New York: Oxford University Press.

Williams, Daniel K. 2016. Defenders of the Unborn: The Pro-Life Movement before Roe v. Wade. New York: Oxford University Press.

Williams, Pete, and Halimah Abdullah. 2015. "Landmark: Supreme Court Rules Same-Sex Marriage Legal Nationwide.” NBC Nightly News, June 26, 2015. https://www.nbcnews.com/ news/us-news/same-sex-marraige-legal-nationwide-supreme-court-rules-n375551.

Wilson, Joshua C. 2013. The Street Politics of Abortion: Speech, Violence, and America's Culture Wars. Stanford, CA: Stanford University Press.

Wilson, Joshua C., and Amanda Hollis-Brusky. 2018. "Higher Law: Can Christian Conservatives Transform Law through Legal Education?” Law \& Society Review 52 (4): 835-870.

Witte, John Jr. 2007. The Reformation of Rights: Law, Religion, and Human Rights in Early Modern Calvinism. New York: Cambridge University Press.

Wuthnow, Robert. 1988. The Restructuring of American Religion: Society and Faith since World War II. Princeton, NJ: Princeton University Press. 